\title{
Kurdish Transhumance: Pastoral practices in South-east Turkey
}

Michaël Thevenin

Correspondence: veninthe@yahoo. com

6 Rue Mélingue, Paris, 75019

France

\begin{abstract}
Background: In a book dated 2002, there is a map of the Mediterranean region which identifies areas where seasonal movements of sheep flocks still take place. Turkey figures prominently, but only the western part of the country is mentioned. From the eastern part, the Kurdish region, nothing seems to filter through. In fact, for the past 40 years, Kurdish shepherds and their traditions seem to have been forgotten by the pastoral world and also by Kurdish elites. After the period of conflict in the 1980s and 1990s, a general ethnographic updating is due.

Results: Pastoralism in southeast Turkey has two aspects: village pastoralism and pastoralism with vertical and horizontal movements. The latter comes in many forms and is practiced by seminomads or nomads within complex issues of identity.

Conclusions: The daily lives of these Kurdish shepherds are affected by the changes in their environment and the difficulties of the Turkish nation at whole. Today, Kurdish pastoralism is a heritage that remains to be assessed, which includes an example of enclosed nomadism in a settled context, that is able to persist notwithstanding its adaptability and malleability.
\end{abstract}

Keywords: Turkey, pastoralists, Kurds, transhumance; seminomadic, nomadic; tribe

\section{Introduction}

"Why are you interested in them? There are so many beautiful things to see here!"

How many times have I heard or read this expression on the face of Kurdish guides who accompanied me to see the shepherds? Sometimes it is said mockingly; sometimes, with genuine astonishment. Some would urge me to climb Mount Ararat; others, to visit Akdamar or even to attend a festival. However, I remained disturbingly obsessed with the shepherds and their sheep.

Why focus on Kurdish pastoralism?

- Because, for the past 40 years, Kurdish shepherds and their traditions seem to have been forgotten by the pastoral world and also by Kurdish elites. During the twentieth century, this way of life has undergone, like many others elsewhere, profound social and economic changes, often in a violent manner, which have also changed its cultural identity. After the period of conflict in the 1980s and 1990s, an ethnographic updating is due.

- Because Turkey is knocking at Europe's door. Turkey has 22 million sheep (Richet 2011) husbandry practices ranging from unrestrained modernity to one of 
the most emblematic ancient cultures: transhumant nomadic and seminomadic pastoralism. What would be the future of the latter under possible European Union membership?

- Because the Kurdish people represent 15 to 18 million people in Turkey; they are the largest population without a country in the world and a major population of the Near East that has become a minority with the advent of the nation-state. This situation has heightened the question of identity within a country that has already been heavily marked by ethnic or religious conflicts (the Armenian genocide, Alevi massacres, Kurdish guerilla movements). How are identity issues articulated in the pastoral practices of southeastern Anatolia in Turkey at the beginning of the twenty-first century?

- Because Kurdish shepherds settled in the area north of the ancient Fertile Crescent, a region that undoubtedly witnessed the domestication of sheep about 8,000 years ago and pastoralism in its wake. Twenty years ago, 97\% of Turkey's sheep population was composed of local breeds (Askin et al. 1989). These circumstances provide a wealth of zootechnical, ethnozootechnical, and genetic data to exploit.

- Finally, Kurdish pastoralism opens up an additional issue: that of sustainable development in a nomadic territory. Indeed, the actions against nomadic or seminomadic practices that have been carried out by agrarian and environmental policies in neighboring Iran (Digard and Papoli-Yazdi 2008,) or in Iraqi Kurdistan (Walliser 2011) lead us to strongly question whether sustainable development is possible to protect these traditional methods. However, Kurdish pastoralism still exists in Turkey; should it be protected?

Kurdish pastoralism is thus a combination of a surprisingly wide range of subject matters that blend the complexity of the geopolitical situation of this people with its diversity, the historical wealth of the geographical region within which the people reside, and that of their pastoral affiliation with its enduring traditions, vivacity and modernity when addressing global issues. Finally, there is the question of building a Kurdish pastoral identity and its relationship to the territory within a changing world. It will therefore be apparent that the sole topic, 'Kurdish pastoralism', hardly reflects the complexity of present-day conditions. We will see that Kurdish pastoralism takes many forms, and we will try to explain the possible causes of the differences.

\section{Methods: a look at Kurdish pastoralism through six study tours}

This study is the result of a personal project conducted over six trips to southeast Anatolia between 2005 and 2011, each of which lasted for about 15 days. I changed the dates and periods of my trips to diversify the examples and places visited and to provide a resulting overview since an extensive single period of ethnographic research was not possible. Periods of Kurdish transhumance were given priority in planning the timing of my trips. This corresponds to the months of April and May. Then, I made a trip during a summer in July. The winter period still remains to be studied. Whenever possible, I devoted $24 \mathrm{~h}$ to each family of sheep herders that I met and kept in touch with them with the aim of meeting them again in the event of another trip, intending also to give them the photos that I had taken of them. 
In the field, my questions were initially and exclusively devoted in determining the geographical transhumance routes of the sheperds and recording their family (tribe membership or isolated family), religious affiliations, forms of managing livestock (transhumant, seminomadic, or nomadic), and what they produced. Secondly, I gleaned more general information on pastoral practices, including the number of animals owned, the type of sheep they kept, and why these types were kept.

I added to the information my own immediate and recorded photographic observations. Therefore, the material described below stems from the exchanges and images gathered during my various stays, the combination of my independent nonacademic status, and the geopolitical situation of the area in question, which prevented me from gaining access to more official documents or quantitative data.

Finally, I was particularly concerned to explain to these families the focus of my work by showing them the book entitled 'Transhumances: a relic of the past or a future practice?' published by the Maison de la Transhumance (Fabre 2002), in which a map of the Mediterranean identifies areas where seasonal movements of flocks of sheep still take place. Turkey figures prominently next to Spain, France, Italy, the former Yugoslavia, and its immediate neighbors, Greece, Bulgaria, and Romania, yet only the western part of Turkey is mentioned. From the wall of silence imposed on its eastern part, the Kurdish region, nothing seems to filter through. However, these families were indeed there in front of me with their sheep, proving the existence of sheep-rearing practices in eastern Turkey. So what about Kurdish pastoralism? The aim of this article is to provide some answers.

\section{Kurdish pastoralism}

Pastoralism in southeast Turkey has two forms: village-based sedentary pastoralism and pastoralism with vertical or horizontal movements. The latter takes many forms. It may take the form of local transhumance, normal (sheep are based in the villages of the plain and ascend the mountain pastures in summer) or reverse (sheep are based in mountain villages and come down during the winter onto lowland pastures), or it may comprise regional or interregional trips, sometimes with double migration (sheep are based in villages in the foothills, descend to the lowland pastures in winter, and climb to the mountain pastures in summer). Transhumance is carried out by seminomads or nomads on foot, truck, or a mix of both. Kurdish nomadism involves the mobility of a part of the family group depending on the season. Indeed, inside the tents or camps of the transhumants encountered, the members of the nuclear family (parents and children) or the extended family (grandparents, in-laws, uncles, and aunts) live side-by-side. The seminomadic people live during the winter months in villages, inside permanent homes, unlike the nomads who camp the whole year in tents even if they appear to be attached to 'mother' regions when there are double migrations. This aspect still needs to be studied.

This diversity in Anatolian pastoral practices had already been noted by (Frödin (1944),) and (Yalçin (1986),). Concerning the Kurds, (Frödin (1944)) differentiates the tribes from the northeast of Anatolia, practicing vertical or horizontal local transhumance, and the tribes from the southeast practicing long-distance vertical transhumance.

These patterns are related to the physical and climatic characteristics found in eastern Turkey (see maps in Figures 1, 2, 3, 4). To the north of this region, forming an arc 

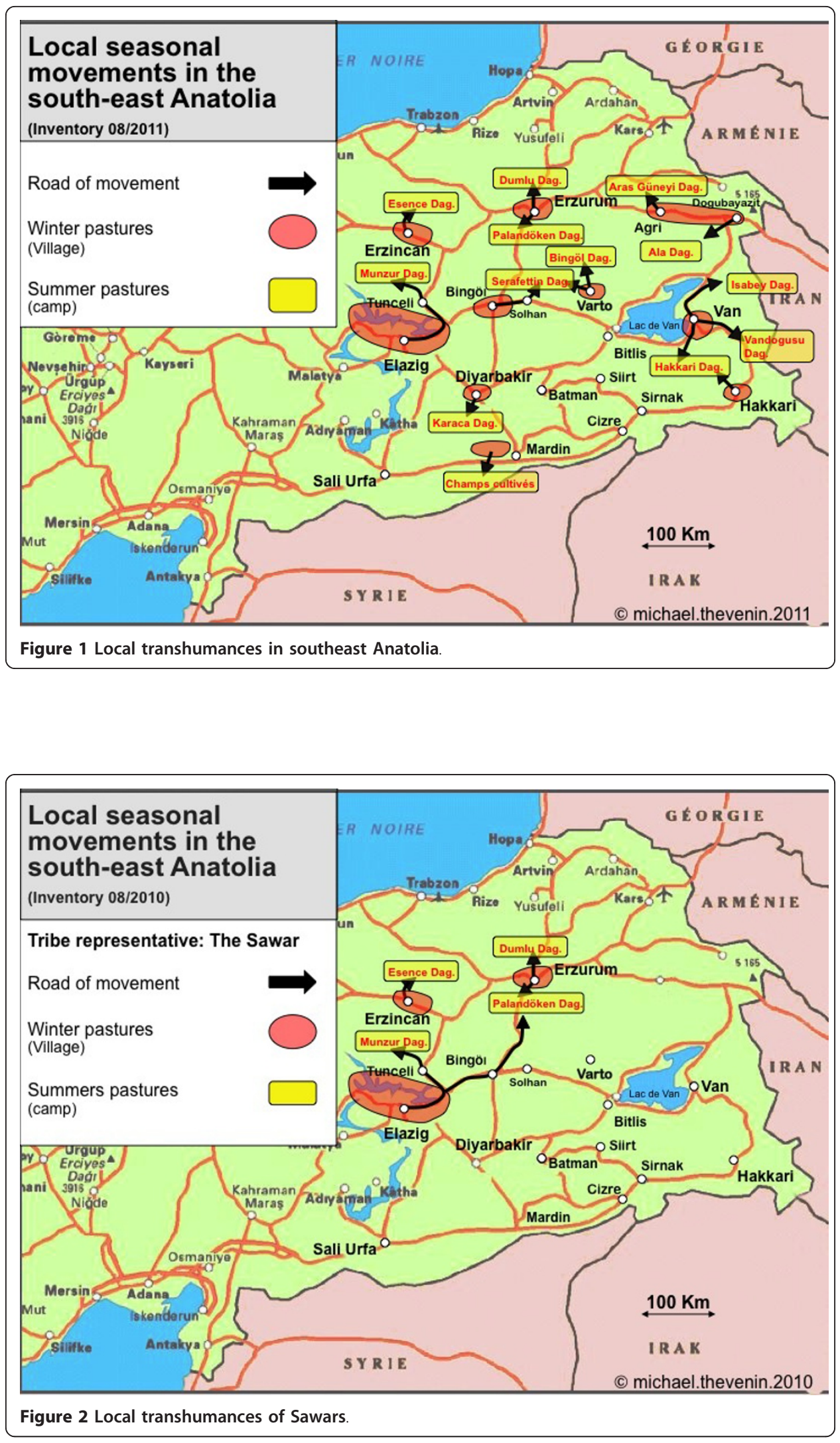

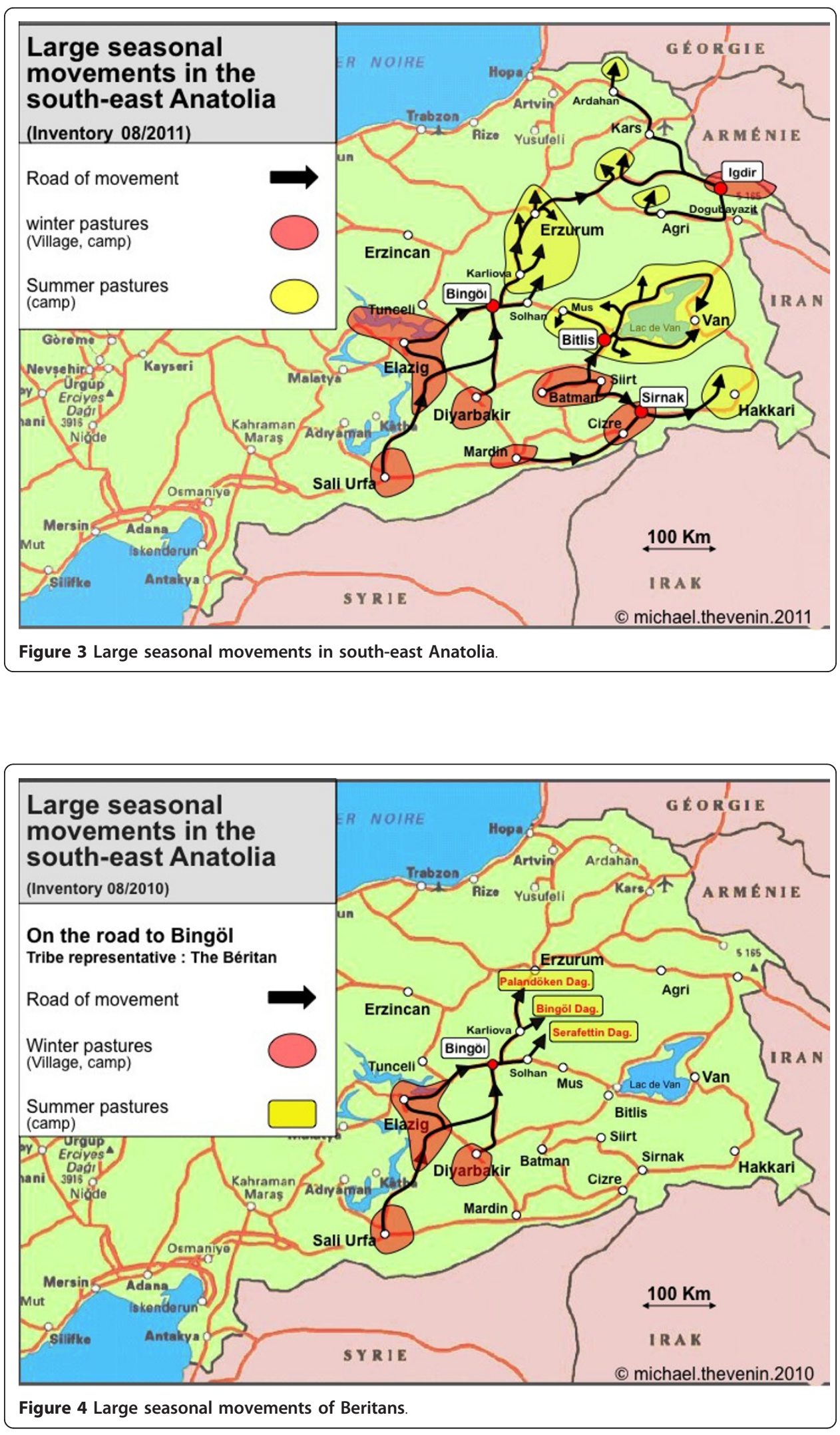
from the west to the east around the plain of Diyarbakir, are the Kurdish Taurus mountains; lower toward the south in a troubled region, there is a succession of valleys, hills, and plains lying between 700 and 2,000 m.a.s.l.; and to the south is an extension of the semiarid Syrian steppe (Fleming 1991).

Moreover, young isolated volcanic mountains are located to the east (Ararat, Nemrut, Süphan, and Tendurek). High plateaux are found between 1,500 to 2,000 m.a.s.l in the center of Anatolia, at 2,000 to 2,500 m.a.s.l) in the northeast part of Anatolia (Atalay 2000).

Pastures occupy around $27 \%$ of the total land surface of Turkey. They can be classified into six main ecological regions depending on the ecology, the use of the soils, and the type of pasture: (1) steppes, (2) high steppes or high grass, (3) anthropic steppe, (4) alpine and subalpine pastures, (5) forest, and (6) scrubland and garrigue (a plant community characteristic of Mediterranean regions, similar to scrub) (Atalay 2000).

The locations we are interested in include the steppe regions, where the mean annual rainfall is below $400 \mathrm{~mm}$, covering interior Anatolia and the southeast plateau, the high grass and high steppes that occupy the east and northeast of Anatolia governed by a subhumid continental climate with an annual precipitation above $500 \mathrm{~mm}$, and the alpine and subalpine pastures which dominate the Taurus mountains and are spread over the southern part of Anatolia. Those areas constitute the main pastures used by the nomadic and seminomadic Kurdish populations (Atalay 2000).

Whether village-based or transhumant pastoralism, similarities exist between groups: a process of self-sufficiency largely governs the whole of agriculture in interior and oriental Anatolia (De Tapia 2007). Products sold mainly consist of meat (from lambs) and dairy products (cheese from sheep and cow's milk, yogurt, and butter) The beverage made from milk, water, and salt, called ayran in Turkish and daw in Kurdish, is prepared only for family use (Figures 5 and 6).

Wool is also sold, but its contribution to household economies is minor. Twenty years ago, mutton represented $43 \%$ of the country's total production of red meat, and sheep's milk represented 22.4\% of milk production (Askin et al. 1989,). The overall use of products from sheep evidently has a role in the choices made by Kurdish farmers in animal breeding - to breed robust races that necessarily have a lower yield in terms of production. Nevertheless, it is acknowledged that sheep farming is an industry that brings in money, which contributes greatly to the country's economy (Askin et al. 1989).

Sheep meat is sold in regional or national markets according to the location of slaughterhouses. Milk is sold at local and regional markets (in fact, I met a dairy product wholesaler who had travelled $200 \mathrm{~km}$ from his store to pick up his merchandise). Further work is needed on the marketing practices for Kurdish meat and dairy products.

It should be noted that the families I studied no longer make woolen rugs. This activity seems to have disappeared from the pastoralist customs of eastern Anatolia.

The flocks are usually guarded by two shepherds (one for the night and one for the day) with three guard dogs and sometimes, a gun (wolves are still numerous in these regions). There are no sheep herding dogs because the human workforce is available. 


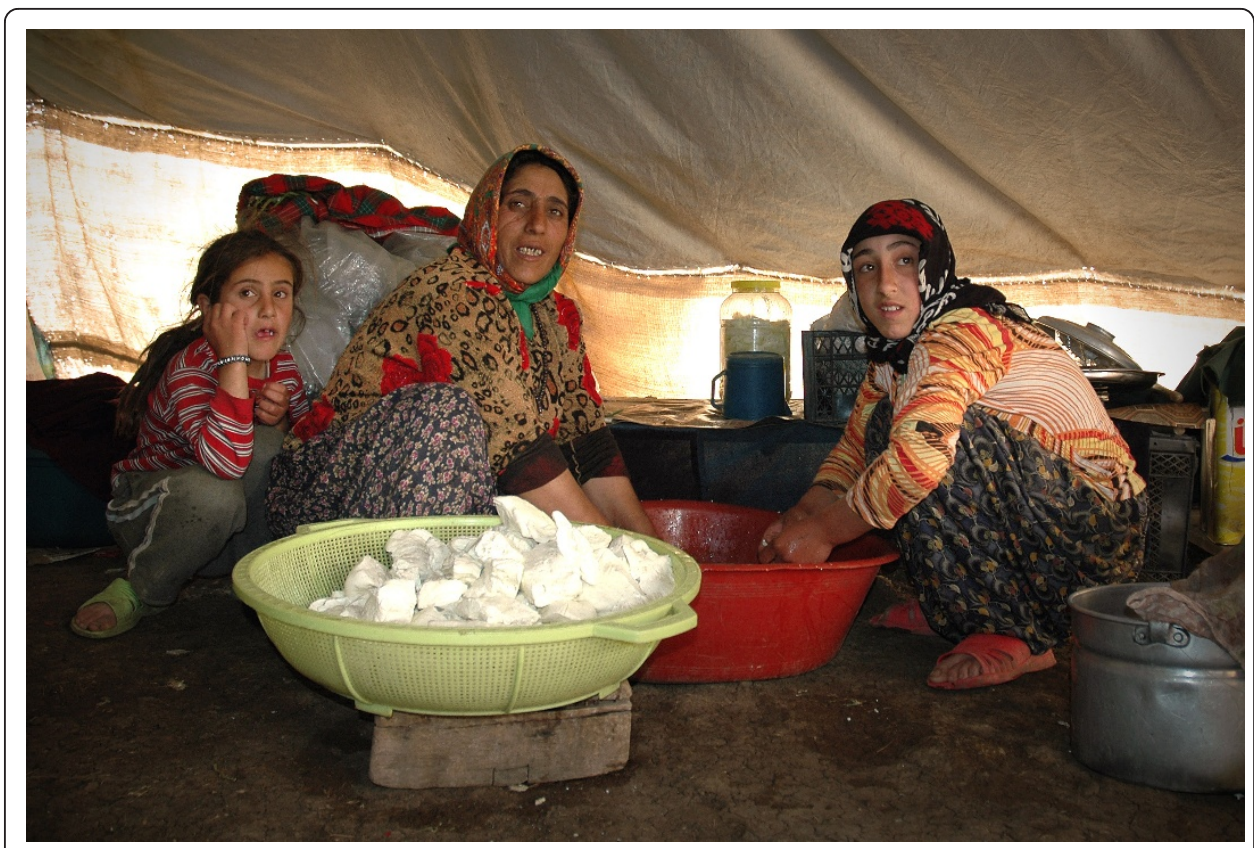

Figure 5 Cheese making in a Beritan family in Solhan, June 2008

The number of animals in a flock varies between 400 and 500 heads, depending on whether they belong to a nomadic or seminomadic family or to an entire village.

\section{Village-based sedentary pastoralism}

This is pastoralism without transhumance or nomadism and was not covered in detail in my study. Turkish agriculture in interior and southeast Anatolia (de Tapia 2007,) has a strong peasant character, with a predominance of small family farms (Tekelioghu

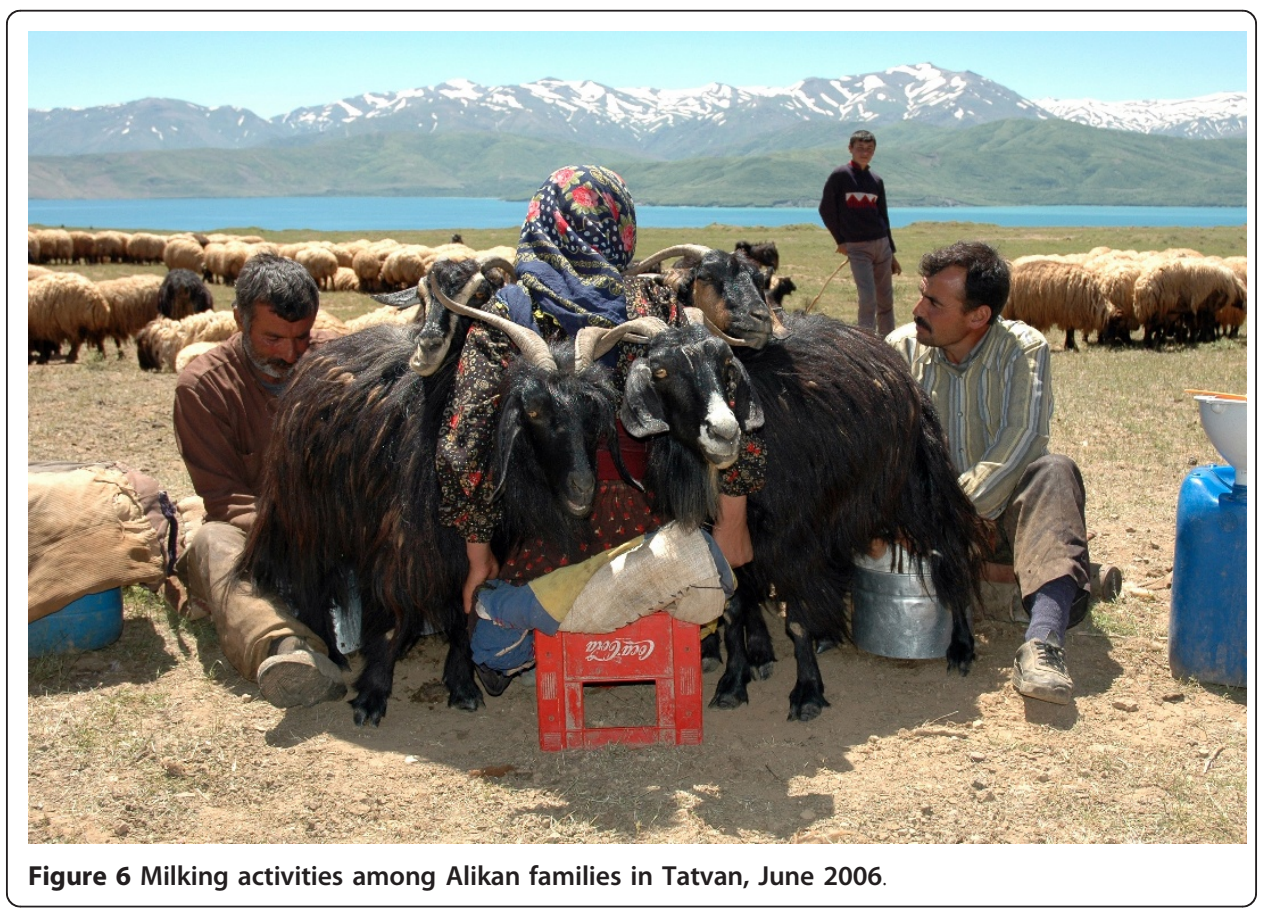


1993), and the Kurdish village-based sedentary pastoralism follows this pattern. It appears to be entirely linked to the village, based on individual holdings (farms), which focus mainly on sheep breeding. One could also consider the nomadic 'family farms' of the Kurdish tribes, farms in their own right.

In the mountain villages, the most important economical activity is sheep breeding. Generally, crop cultivation is only for the household and animal consumptions. Wheat, maize, and hay meadows are dominant crops. There is a low mechanization as reported by the low use of tractors. In the mountains, the villagers are generally owners of the land, contrary to the plain villages where the property of the cultivated soils belongs to the tribal chefs or aghas (Gündüz-Hosgör and Smits 2006). Each family owns livestock (cows or sheep) in variable numbers depending on their wealth. At the beginning of spring, the ewes are regrouped in flocks, sent to the pastures, and watched by the shepherds. The flocks are kept first around the villages, then on the cultivated fields before the seeding period, and then further, on meadows exclusively reserved for pasture until the middle of summer. At the end of August, the flocks come back around the villages onto the fields which are now harvested.

Every morning, the women set off to join the sheep, which are sometimes several kilometers away from the village, to milk them. In other cases, the shepherds bring the flocks close to the settlement. Depending on the distance and the environment, the shepherd sometimes installs a tent for a few days on a particular grazing field as we have seen in the region of Dogubayazit in September on grasslands.

\section{Pastoralism with displacement (seasonal movements)}

The seasonal movements are presented with reference to tribal communities which are recognized either within Kurdish communities or by others outside, which are well known at local and regional levels in the entire Anatolian Kurdish sphere.

Tribal reference can still be found in Turkey as was demonstrated by (Gokalp (1987),) with his study on the integration of Oghouz tribal systems in Anatolian villages. For the Kurds, this tribal reference has been strengthened by the establishment of modern centralized states 'at least because of the new resources that the tribes could exploit' (Van Bruinessen 2000,). Democracy and the multiparty system, new borders and the consequent development of smuggling, and finally, the Kurdistan Workers' Party [PKK] guerilla and its contra-guerillas have all opportunities for tribalism (Van Bruinessen 2000).

\section{Local transhumances (figure 1)}

Local transhumance with vertical displacement takes place in most mountain valleys and in the lower foothills of the Taurus mountains (Tunceli, Erzincan, Erzurum, and formerly Varto, Van, Hakkari, and north of Sirnak; Johnson 1969).

We first focus on transhumance practiced on an axis that connects the region of Elazig to Erzurum through the pastures of Tunceli (Mountain of Munzur), Erzincan (Mountain of Esence), and Erzorum (Mountain of Palendoken) (Figure 2).

The tribe that is representative of this axis is the Sawar or Shawaks tribe. They carry out local seminomadic transhumances. This community speaks Kurmanji and is of the Alevi faith. The Alevi faith is a moderate version of Islam. It is based on faith in Allah, the prophet Muhammad, and Ali the Holy. This belief was already considered heretical by the Sunni Ottoman central government. Today, Alevis face two types of discrimination: religious and cultural (Wikipedia,). Due to this, the camps of Sawar are often located in Alevi 
places of resistance which have become under significant Turkish army control. Alevism, to which $20 \%$ to $30 \%$ of the total population of Turkey belong (Rollan 2004,), suffered a bloody repression from the 1970s to the 1990s, which led to Alevism becoming radicalized by the action of small, extreme, left-wing groups advocating secularism (Bozarslan 2002).

Therefore, the Sawars 'benefit' from Alevi identity activism, which outnumbers them by far, as does the reputation of the National Park of Munzur, in which some of them camp each year. Thus, during the cultural festival of Munzur, which takes place in July in Tunceli, one comes across a stand selling DVDs and photos about the shepherding Sawar. Furthermore, a documentary by (Öz (2008),) that covers a year in the life of this tribe, was aired on French-German ARTE in January 2008. However, (Van Bruinessen (2001),) does not cite them in his speech devoted to the ethnic identity of Kurdish Alevis. This might suggest that in the past, this tribe has not played an effective role in the claims of the Alevis, unlike, for example, the Xurêmek tribe encountered on the alpine slopes of the Bingöl massif and cited as the Hormek by (Van Bruinessen (2001),). The groups which share the term 'Dersimi' (an inhabitant of the Tunceli region) are composed of two distinct linguistic regions, with the Sawars, a Kurmandji-speaking Alevi tribe, believed to have originated in eastern Dersim (Van Bruinessen 2001) Some Sawars would have moved to the southwest toward Elazig (Cemisgezek, Pertek) and also to the farther east toward Erzurum. The Sawars seem to only possess canvas tents in the form of a semi-open umbrella made of white cotton with a single pillar (Figure 7).

Their camps do not show any sign of permanent structure (low wall, enduring planning, etc.) since they rent the pastures and move the locations of their camp each year. They have a practice, but only on a small scale, of using bells among their herds which is, according to my observations, unique among Kurdish shepherds. Sometimes, families employ shepherds during the summer, for example from Diyarbakir, as

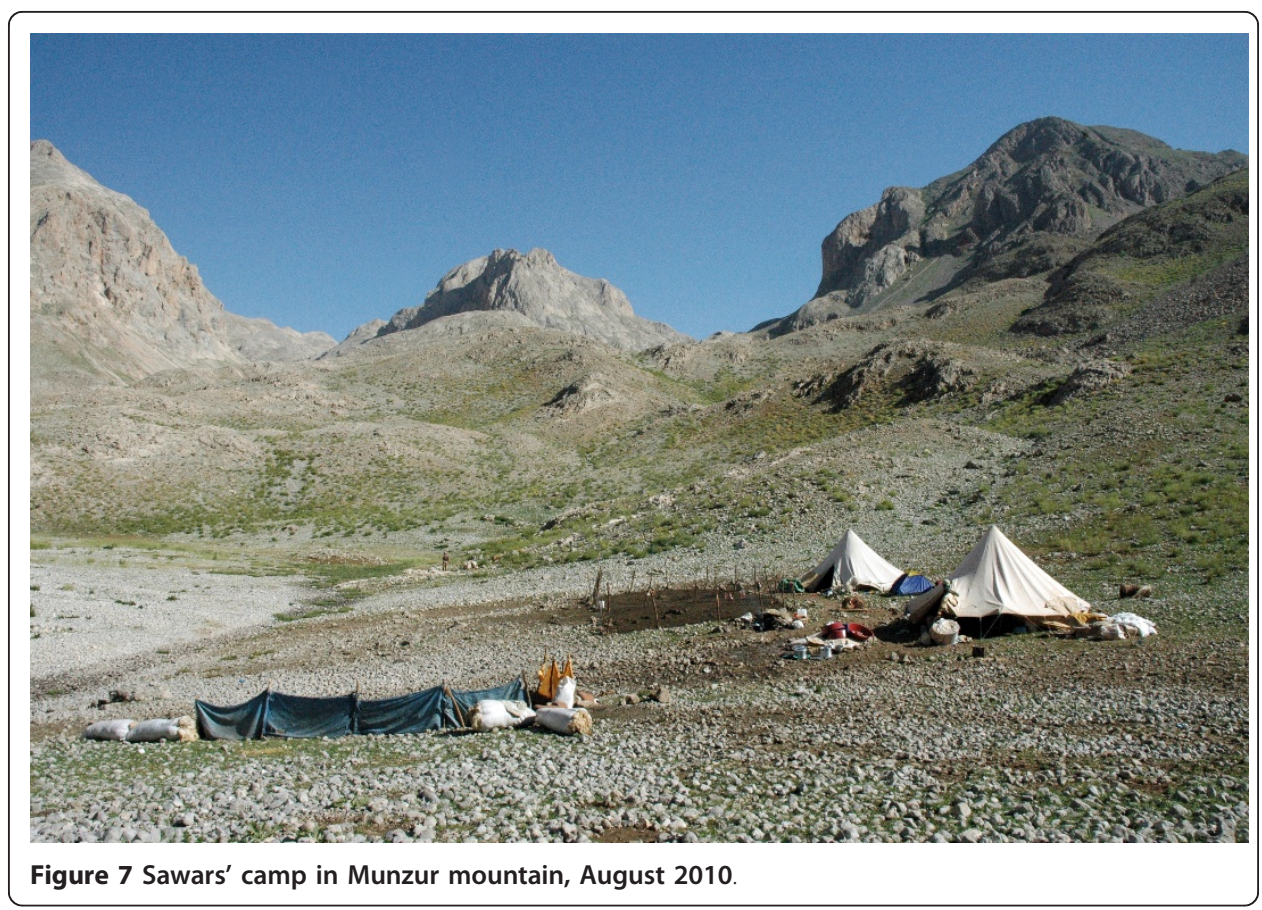


witnessed on the pastures of the massif Esence. This practice is also common among other non-Sawar families, which practice short-distance vertical transhumance at places such as the alpine massif of Bingöl. Some of these shepherds from Diyarbakir are accompanied by their families. Along with transhumance, there is thus another underlying migration: that of hired shepherds.

The sheep belonging to the Sawar tend to be white with a fat tail. It is called Qerkas peze or Karaman peze by Sawar cattle breeders and Savak peze by the other Kurdish tribes. Do we have one or several races here? Is this the Akkaraman race? We cannot say.

Another example of local vertical transhumance can be seen on the heights near Hakkari in the far southeast corner of Turkey with the Erdusî and Peniyaniçî tribes. These tribes own their pastures as the real proprietors with their villages below. In their camps, standardized tents, like for the Sawar, are not typical. Instead, the camps are a vast display of various shelters combining permanent and temporary structures: a mix of traditional vellum made of goatskin, nylon canvas cover, and cotton cloth, covering small walls of dry stones. The Erdusî, however, favor modern tubular shelters without walls and supported by interior arches, observed only there during my whole investigations.

Moreover, water management is also distinctive among the Erdusî and Peniyaniçî tribes. Spring-supplied conduits seem to have been designed in order for every tent, or at least everyone intended for domestic chores (we will comment on this issue later), to be run across by a trickle, bringing running water to each family. The Erdusî have set small tipis called kêpi across these streams, under which they keep dairy products, vegetables, and fruits fresh in the water. This preservation technique is unique. In a summer pasture camp above Tekman, holes of at least 70-cm deep and 1-m wide have been dug inside the tents to preserve the same perishable goods. I cannot tell if this technique is more common than the other. What is clear, though, is that these arragements of conduits and holes become relevant only in the case of permanent settling.

The Erdusî and Peniyaniçî tribes possess sheep of the Hîmdanî and Qerkas breeds. Those two types will be described later on. These pastoralist breeders use the Himdanî breed to improve their stock by crossbreeding them with the hardier Qerkas breed.

In addition to traditional seasonal migration, in parallel, there are other types of local pastoral transfers described elsewhere (Thevenin 2008), such as those practiced in the region of Mardin (reverse transhumance) or another unusual form (horizontal short displacement), involving 300 people, which takes place in the Diyadin region and stems from the fighting between the PKK and the Turkish army. The horizontal short displacement can be found on the high plateaux of the northern part of eastern Anatolia. This movement is a dozen kilometer length between the villages and the summer pasture camps. This kind of camp usually gathers pastoralist families from two or three villages and is therefore generally multi-tribal and sometimes bi-confessional (Alevi and Sunni). The camps are normally no further higher than $300 \mathrm{~m}$ from the home village. In these cases, it is not a change in temperature and environment which is sought but a means of moving the flocks away during haymaking time. Thus, the summer camp is abandoned as early as mid-August for the village. Besides in Diyadin, this kind of pastoralism was observed on the heights of Tekman and Ardahan. 


\section{Large-scale transhumances (Figure 3)}

Long-distance transhumances are practiced by seminomads and nomads.

'As Xavier de Planhol was among the first to observe, large-scale nomadic and seminomadic Kurdish transhumances appeared following the arrival in large numbers of Turkoman tribesmen in eastern Anatolia from the eleventh century onwards [that] gave rise to an intense cultural exchange and the emergence of a new type of pastoral nomadism (combining short-distance vertical transhumances for the Kurds and horizontal migrations for the Turkmen)'(Van Bruinessen 2001),

This nomadism was qualified as 'enclosed nomadism' by the historian (Rowton (1974),). By this, he was referring to a socioeconomic organization that developed far away from the 'external' nomadism of the Iranian and Arabian plateaux as enclosed nomadism was instead in a direct contact with urban civilization settled in the 'pastoral enclaves' of the steppes and mountains of Mesopotamia (James 2011).

From my most recent research, it appears that there are four major axes of seasonal interregional vertical migrations; four routes that are each characterized by distinct emblematic tribes:

- The Beritan tribe is found on the route to Bingöl

- The Alikans and the Mamadîs are the referential tribes of the Bitlis route

- The Dudirans are the referential tribe of the Sirnak route

- Finally, in the area bordering Armenia, there are seasonal long-range movements by Kurdish shepherds, from the Igdir plain toward the Agri, Kars, and Ardahan mountains. In this area, no single representative tribe has been identified so far.

\section{The road to Bingöl}

This axis connects the wintering areas composed of the Elazig, Diyarbakir, and Urfa triangle to the alpine pastures situated above Karliova. Here, a representative transhumance of the Beritan tribe is found (Figure 4).

The Beritan tribe is divided in three clans (mala in Kurmandji): the Kocî, the Kerkulaxî, and the Mîlemerân that are distributed in three distinct mountain pasture regions. The Mîlemeran is not discussed as I have no information on them. Pasture distribution between the clans of one tribe seems to be a common trait of the Kurds. Indeed, we encounter the same phenomenon for the Mamadî tribe on the route of Bitlis.

The Kocî clan meet on the mountain pastures of the Mount Bingöl and Palendoken in summer and on the Urfa pastures in winter. They travel on their transhumance by foot. Their mother region seems to be the Elazig region, from which some carry out double migration. Unique among the nomadic tribes practicing long-distance movements, some Kocî families possess their mountain pastures, for example, the Sawutî zozane on Mount Bïngol which has belonged to the same family for 116 years. Moreover, there is a cemetery of nomadic shepherds in that pasture location.

The Kerkulaxî clan is on the west mountainside of Mount Serafettin in summer and around Diyarbakir in winter. Some of its members formed a corporate group of sheep and cattle traders, with a logo, whose headquarters is located in Diyarbakir. For 
Kerkulaxî families from Diyarbakir, a part of their transport is done by truck to Solhan, a small town in eastern Bingöl, where a small temporary camp is set up. From there, the men and their flocks set off on foot through the mountains to reach the summer pastures located about $50 \mathrm{~km}$ away, while the women, elderly, and children remain in the temporary camp. Women prepare bread and cheese, the staple food that a shepherd will periodically pick up en route, thus maintaining the contact between the flock and the camp. In this temporary neighborhood, the traditional tents (Figure 8), known as the kone res in Kurdish (literally, 'black tents') are not erected yet. Plastic sheeting and nylon fabrics, which are lighter and faster to assemble, are used instead. Thus, each family owns several tents that will be erected according to the installation time and the type of pastures, as noted by (Papoli-Yazdi (1991),). Once the flock has passed the halfway time period, the camp will finally move to its main summer residence. The black tents are then assembled. Among the Kerkulaxî families, these tents are stored as a representation of identity (in the manner of the logo of their corporation), a symbol used as a simple flag, as noted by among the Moors in Mauritania (Boulay 2004).

Thus, the black tent is the tent of the nomads. This is confirmed without ambiguity in the words of the villagers or those of sheep breeders, whether nomadic or seminomadic. Thus, the word koçer ('nomadic' in Kurmanji) is directly associated with the word Kone res (black tent in Kurmanji), which is not the case for seminomads.

The black tent of the Kurdish nomads belongs to the great family of nomadic black tents that we encounter over a large belt from Morocco to Tibet. The Kurdish black tent could be a part of the Iranian black tent type according to the classification of (Feilberg (1944)). The tent consists of a vellum made originally with tissue bands of goat hair sewn together, put under tension by a quantity of six to ten wooden posts, and aligned on two or sometimes three rows depending on the wealth of its owner.

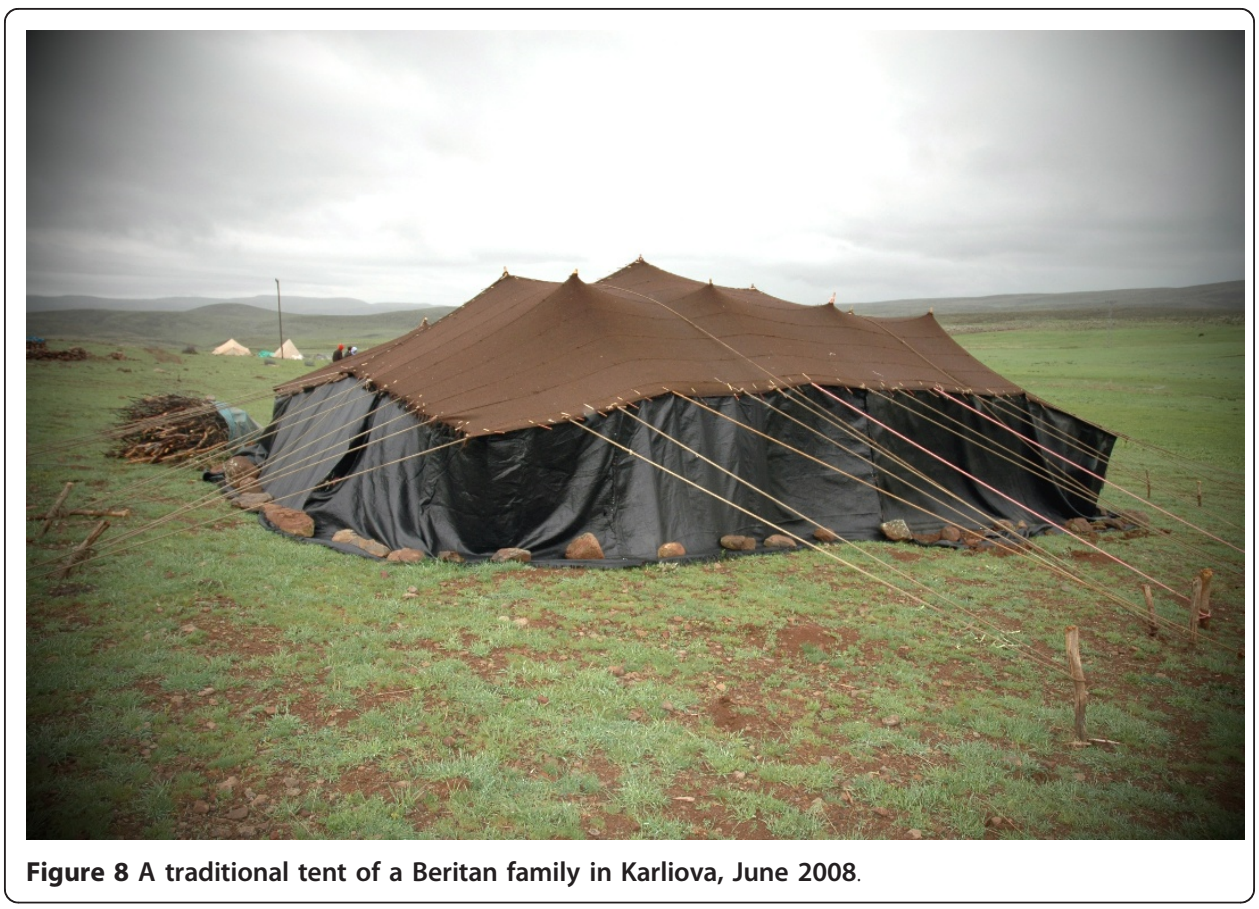


A more detailed study of those tents should be proposed because each tribe encountered has its own version of the black tent as we will see with the Alikan tribe. Indeed, the traditional material has become scarce with the abandonment of goat breeding, which provides the goat hair. Production of tents on the mountains seems to have disappeared, forcing farmers to buy their equipment in stores, to use other materials such as cotton fabrics to repair their traditional tents, or as in the case of the Beritan tribe, to get rid of them completely.

Hence, today on the mountain pastures in summer, the whole of the Beritan camps are mostly composed of umbrella-type tents in white cotton cloth, as the one described for the Sawar, or in nylon. The traditional form of the black tent is sometimes preserved. In this case, only the vellum has changed. For most of the Beritan shepherds encountered, new materials like nylon were adopted because they offer greater convenience even though the black tent remains more prestigious. Moreover, when the latter remains, it is often upgraded with a nylon lining (Figure 9).

Among many of the herds encountered upon the route, two breeds of sheep appeared to dominate: one is the Pezé Sipi type (literally, 'white sheep'), often also called Pezé Qerkas. It is a white, fat-tailed sheep that withstands the heat. It is often the sheep of seminomadic transhumant pastoralists. Descending from this variety, according to the pastoralists, we also met the Pezé Zom type of the Beritan and Karahan pastoralists (another tribe on the road to Bingöl). This variety differs from the original stock, having black muzzles and eye contours. Some Beritan sheep breeders actively select this type.

The second breed is the Pezé Sor type, (literally, 'red sheep'), also called Moorpez. It is a more rustic brown, fat-tailed sheep that is more resistant to the cold. It was traditionally the sheep of the nomadic Beritan tribe. Today, their livestock have the Pezé

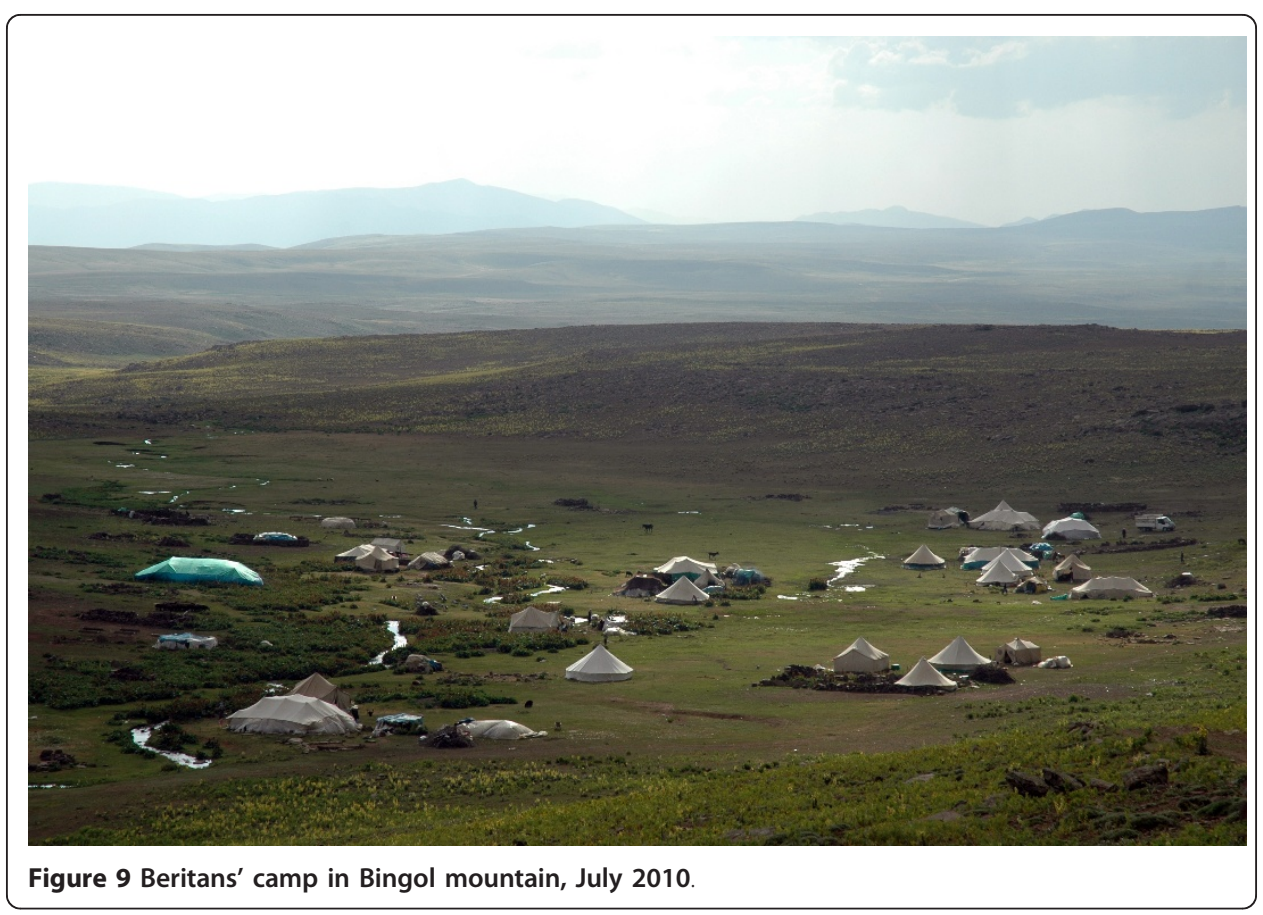


Sipi and the Pézé Sor. The Peze Sor is not found among seminomadic Karahan or Sawar tribes.

Are these two types of white and brown sheep the Akkaraman and Morkaraman of the Turkish census (Askin et al. 1989,)? (Yalçin (1986)) confirms this hypothesis in his book "Sheep and Goats in Turkey". In the second case, the name Moorpez, which was given by some Kurdish breeders to the Pezé Sor type, would tend to confirm that the mixture of the Kurmanji and Turkish languages is fairly common in southeast Anatolia.

'The White Karaman (Akkaraman) is an indigenous breed of Turkey. Like the other fat-tailed sheep breeds in the country, it is very hardy and strives well under poor feeding and extreme climatic conditions. The white Karaman breed is distributed throughout Central Anatolia and into the parts of the eastern and southeastern regions. It is also found in the parts of the Black Sea and the Mediterranean regions adjacent to Central Anatolia. The White Karaman covers approximately half of the country's surface area. It has the largest population among the sheep breeds of the country; in 1983, it numbered 21 million or $43.2 \%$ of the total sheep population.' (Yalçin, 1986)

"The Red Karaman (MorKaraman) bears some similarities with the White Karaman and in fact, carries the word Karaman in its name. According to (Mason (1967)), however, it merits classification as a separate breed, along with the White Karaman, and not merely as a color variant of the Karaman. The Turkish names Kizil Karaman and Mor Karaman are used for the breed, often interchangeably, because of its reddish-brown color. Kizil is the Turkish word for red and Mor is the Turkish word for maroon. The Red Karaman is distributed in the northeastern provinces of Turkey, namely Kars, Erzurum, Agri, Muş, Bingöl, Van, Bitlis, Erzincan, and Elaziğ. The number of Red Karaman sheep in Turkey in 1983 was estimated to be 11.9 million; this corresponds to $24.4 \%$ of the total sheep population of the country.' (Yalçin, 1986)

\section{The route of Bitlis}

The third axis connects the regions of Batman and Siirt to the pastures of Varto and to those around Lake Van as well as those of Hakkari, near the Iraqi border. Transhumance by truck is the most common practice here. The mixing of transhumance practices can be found, as some pastoralists return on foot in November, as is done by some of the Alikan families settled near Van. The seasonal paths of this axis have been identified previously (Hütteroth 1959).

A particular circuit is used by families of a tribe called Dudiran from Siirt. We found this tribe mostly on the road to Sirnak. Their summer camps are located on the heights of Hakkari, yet instead of taking the same route on their outward and return journeys, in December, they prefer to return further south to Sirnak, near the Syrian border, before returning to their wintering area near Batman.

The Alikans are the first reference tribe here. They were the subject of a study conducted in the 1960s by a Turkish sociologist, Ishmael Besikci: a study which also landed the researcher in prison for a period (Besikci 1969,), the reason being: violation of the principle of the indivisibility of the Turkish nation (wikipedia). A 'tribe' that is 
'Kurd' could not exist in Turkey during the 1960s, which only acknowledged Sunni Turkish citizens.

There are two salient points to note about the route to Bitlis: First of all, in this place, the typical transhumant sheep is a breed called Cizirî by farmers (pronounced as (djiziri') and sometimes Himdanî. Its physical specificity differentiates it more clearly from the other breeds: having a brown head and legs, yellowish wool, being long and slender, having a large tail (like all Kurdish sheep), and very long ears. This race belonged to one of the Alikan families 40 years ago, when Besikçi (1969) photographed the camps on Mount Nemrut overlooking Lake Van. This breed morphologically resembles the Awassi sheep breed, or Ivesi in Turkish, of which there are 4 million in Turkey. Studies are underway to differentiate local races within this minority population (Flamant 2006,) in the country, which is more than $2 \%$ of the national herd (Askin et al. 1989,). The name Ciziri may be closer to the Awassi variety from Iraq, the sheep breed called Gezirieh (Epstein 1985), and a breed called Djezireh in the Syrian region in the northeast of the country, along the borders with Turkey and Iraq, bordering Lake Van, and also the homonymous Turkish city of Cizre.

The tents of these tribes are quite remarkable. The outside is not systematically decorated with the customary brown bands made of goat hair, but instead consists of a mosaic of various materials with repeated motifs and colors. Squares of fabric, cotton, or synthetic cloths, which in some cases are of urban origin, are pieced together. These pieces are then connected to a collection of patches, thereby creating a mosaic tent (Figure 10). The materials have changed, but the spirit lives on: as with the black tents, only worn parts are replaced. 'The concept of the structure is more important than the perishable material in which it is realized.' (Andrew 1999)

Inside the tents, the awning fabric is actually supported by a nylon canopy, an assembly of large bags commonly used for transporting or storing wool. This material is also

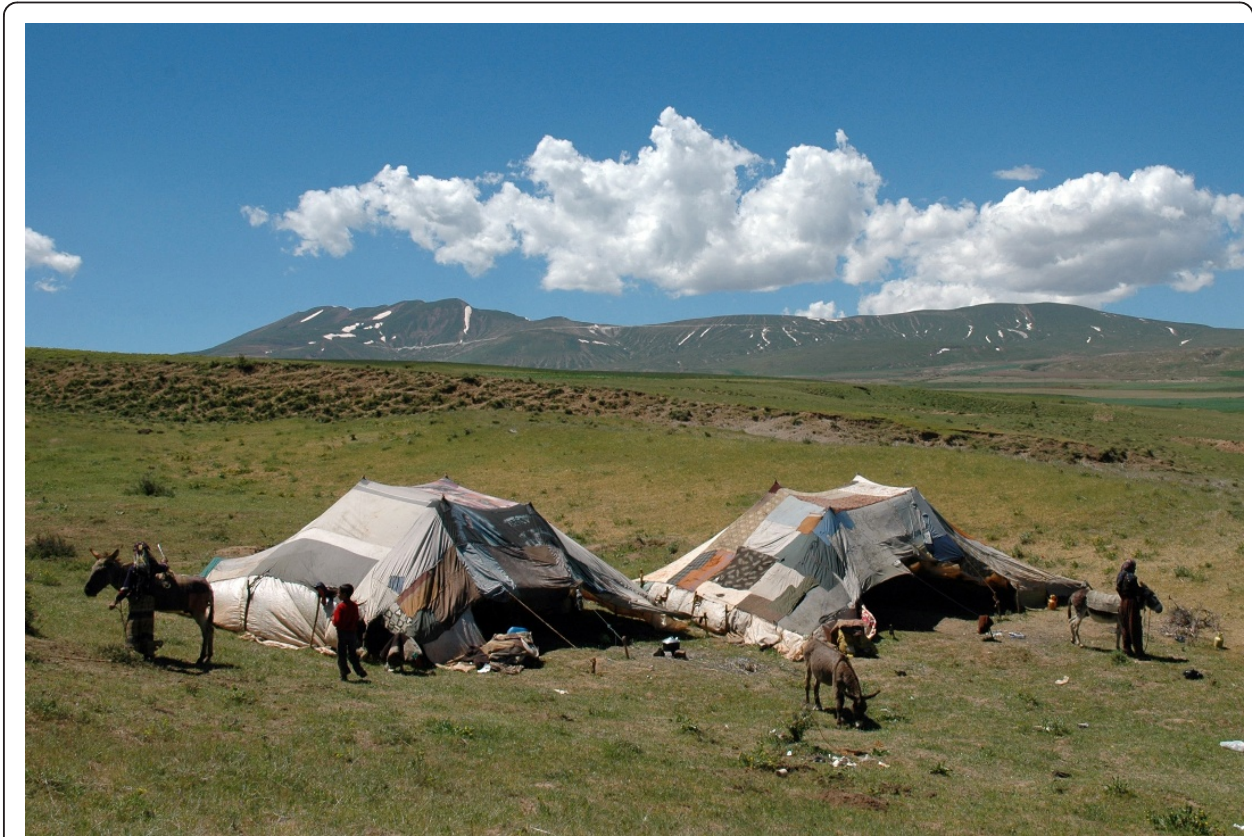

Figure 10 Tents of an Alikan family in Tatvan, June 2006 
adapted for other uses, like feeding the hearth fire or creating a cloak in which the shepherd wraps himself in during the night - a kulav (Figure 11) - when he is far from the camp and has to remain with the flock. Lined with felt, the kulav protects the shepherds against the rain and the cold, and the shepherds huddle inside it to sleep.

The appearance of these modern fabrics instead of the traditional canopy is not an isolated phenomenon. (Papoli-Yazdi (1991)) already described this in the region of Khorasan in Iran in 1982.

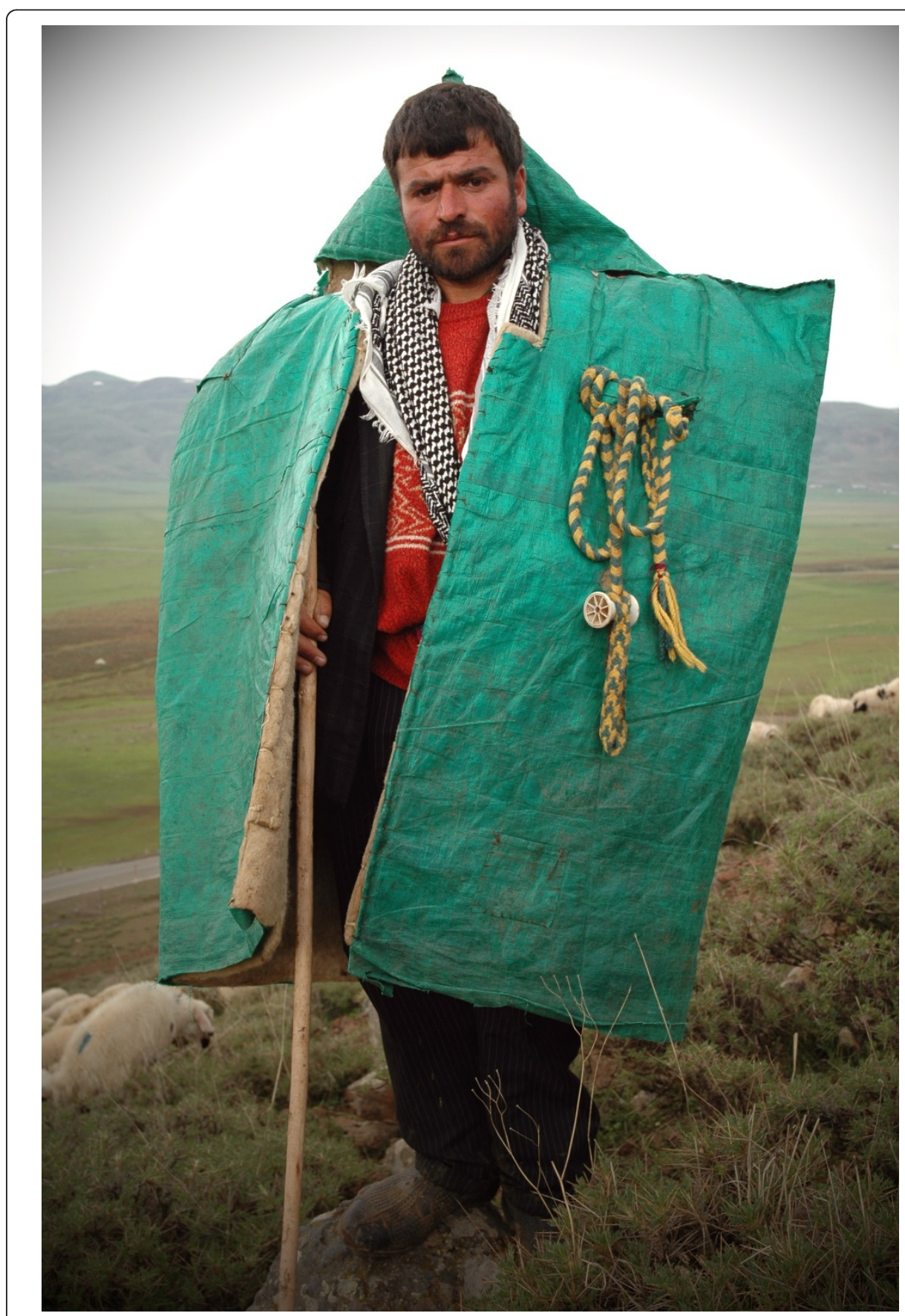

Figure 11 A Beritan shepherd and his kulav in Karliova, May 2008. 
However, among the Alikan tribe, why are there no modern, white cotton tents (umbrella tents) as described for the previous routes or on the seminomadic settlements described above? To date, we can only make assumptions.

Some obviously better-off families, just as the rich Moor families in Mauritania (Boulay 2005) have managed to adopt these new types of shelters in rather remarkable ways, both technically and aesthetically, and it is not rare now to meet camps that consist entirely of these mosaic tents around Lake Van. If these tents were a symbol of poverty, why would they be so present in a world where the terms 'honor' and 'pride' have kept all their meaning? This shows that the cash theory is not sufficient and that the reasons for this singular development are indeed more complexly rooted.

Questioned on this subject, an Alikan shepherd simply answered that the modern tents, whether umbrella tents or in nylon, were not the nomads' tents. This is why the mosaic tents that keep the spirit of the traditional nomadic tent (enabling a partial and gradual renewal of the vellum without obliging the owner to invest in a new tent) and maintain the identity role are preferred by the Alikan tribe than the cotton or nylon tents even if they do not practice nomadism stricto sensu anymore. Indeed, it should be known that for the past few years, there have been several cases of definitive settlement by Alikan families in the city of Van. Those families have not abandoned sheep breeding, but now practice a local transhumance in a form of seminomadism, meeting every summer on the mountain pastures situated on the heights of Lake Van. Some of these families separate from their sheep every winter by selling them and buy new flocks in the spring to produce lambs and cheese.

On the road of Bitlis, we also meet the Mamadî tribe. It is the second reference tribe on this axis. The Mamadîs are seminomadic and live in the winter around Batman. They form three clans, distributed on three different mountain pastures: thus, there are families around the Nemrut Dagi, but also on the heights of Hizan, south from Tatvan, and above Mus. It should also be noted that the camp observed on the side of Mount Nemrut seems to occupy the old location of the Alikan camps described by (Besikci (1969)) more than 40 years ago, which is not surprising in itself. Since the pasturre location is being rented by villagers to nomads and the rental contract renegotiated periodically, the mountain pastures of the tribes can change from 1 year to the next.

The flocks of the Mamadîs are composed of two types of sheep: the cizirî (already described) and also the Pezé hûrik type.This latter type is called 'Herik' by (Yalçin (1986)).

'The Herik sheep are distributed in some provinces along the eastern Black Sea coast and in the provinces adjacent to them (Samsun, Trabzon, Rize, Amasya, Sivas, and Corum). In some of these provinces, it is known as Amasya Herik. A similar sheep also occurs in Van and in the nearby provinces in eastern Anatolia.' (Yalçin 1986)

A distinguishing feature of the Mamadîs' camp, in addition to a different technique in the rope system of the traditionally structured tents (not described here), is the use of water retention tanks for the flocks. Situated above the camp, two tanks with a length of $20 \mathrm{~m} \times 6 \mathrm{~m}$ have been dug and covered by a nylon tarpaulin. In the absence of a spring, these tanks collect the streaming of water from the snow melts. Moreover, 
canals have been built based on the same principle, conferring to this camp a permanent character. Indeed, contrary to the nomadic and seminomadic camps already described that practice long-distance movement, occupying rented or acquired mountain pastures, here, the Mamadîs' camp does not seem to move each year. The location seems to be the same, year after year, like the camps of the Erdusî and Peniyaniçî tribes and those using short-distance horizontal mountain summer pastures. The absence of springs on this mountain pasture has 'anchored' the camp around specific water tank constructions.

\section{The route of Sirnak}

The Sirnak route links the high summer mountain pastures of Hakkâri (we met camps established at more than 3,000 m.a.s.l) to the regions of Batman, Siirt, and Mardin. Families from the Dubiran tribe travel on this route. The Dubirans are nomads. They occupy their pastures in winter as well as in summer. They travel by foot in April and in September for a total of 41 days moving. During the mountain summer pasture period, they sell their lambs, milk, cheese, and fleeces. In winter, they buy grass and nutritional supplements to feed their ewes and when necessary, buy new tents.

The traditional goat vellum of the black tent was abandoned more than 20 years ago by them because it became too hard to transport and produce. Their tents, having kept the same structure as the original black tents, are now in cotton lined by nylon.

In the camps, each family possesses several habitats, each with a precise function (not comparable to the tents of the temporary camps used for intermediate pastures described previously for the Beritan Kerkularî). For example, a family can have a tent for reception, eating, and sleeping, another tent specialized for the production of cheese, and another tent designated for the preparation of meals (the kitchen). Depending on the wealth of the family, one can add a tent for washing, another for women only, and another to shelter sick or wounded ewes. Thus, in a Dudiran camp, one can distinguish groups of individual tents separated from one another, each group comprising a family space. This pattern is found throughout the whole camp, whatever the tribal membership or the type of transhumance, with notable differences in the number of tent units a family possesses, which can range from two to five tents per family.

Depending on the size of the camp, there are also one to three traditional communal ovens called tandur (Figure 12). For the Dudirans and also the Mamadîs, these are made a metal barrel, covered on the inside by dry earth, surrounded on the outside by a dry-stone wall.

For the Alikans and the Peniyaniçîs, the tandur is dug in the ground and can be protected by a small tent. The Karahans and the Beritans do not possess tandur. This type of tandur oven enables baking of a thicker bread than the kind baked on the convex plate that each family otherwise owns.

The Dudiran families encountered had hûrik and cizirî ewes. Interestingly, some Dudiran shepherds make a distinction between himdanî and cizirî, as if they were two different types. This may be a possibility.

\section{The route of Igdir}

Igdir is the prefecture of the province of the same name situated on the border with Armenia. Trapped between two ancient volcanoes culminating at more than 4,000 m.a. 


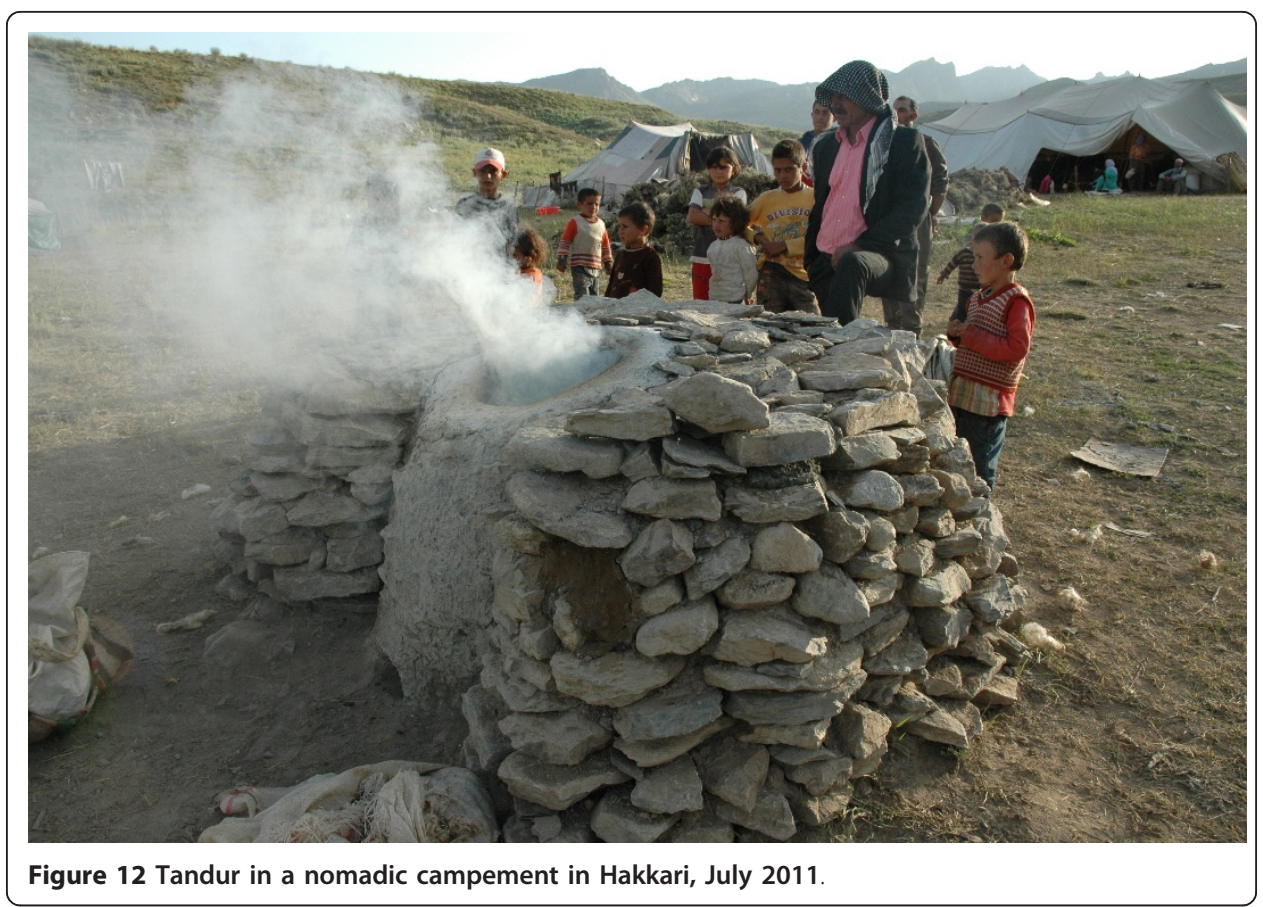

s.l, Mount Ararat in Turkey and Mount Aragac in Armenia, the plain of Igdir is a tectonic depression situated at 800 m.a.s.l where arboriculture is widespread. The population is principally composed of Azéris Shiites and Kurdish Sunnis, the latter having for the most part immigrated from Van, Agri, or Diyarbakir. By tradition and according to the Kurdish sheperds encountered, the Azéri are farmers and the Kurds are sheep breeders. Before the1990s, the latter traveled in the direction of the mountain pastures of Agri, Kars, or Erzurum.

During the hard years of conflicts between the PKK and the Turkish army, the mountain pastures of Agri were closed by the army, forcing the Kurdish breeders to change mountain pastures or their livelihoods. Thus, some Kurds from the Redsanlî tribe abandoned sheep breeding and were hired at the beginning of the 2000s as oxen shepherds by Turkish villagers from the Ardahan region, who were short-handed because of the high out-migration of young men.

Today, numerous Kurdish shepherds come to this region at the request of the village leaders, and some of these Kurds resume sheep breeding with seasonal movements, preferring those villages which are welcoming and better endowed with roads in spite of the more difficult mountain pastures, to the mountain pastures of Agri. Thus, in parallel to the seasonal movements to Agri, Kars, and Erzurum that continues, a new axis of transhumance is being created between Igdir and Ardahan.

\section{Discussion}

We aim to show by these examples that the various forms of Kurdish pastoralism express themselves far beyond Frölin's classifications. We could have added to this classification one more grid based on the geographic distribution of the Kurdish sheep breeds encountered and on the tents (black tents and umbrella tents). This contribution will deserve another study. 
There are several reasons for this variety. We hypothesize that overlaying the previous distinctions, more recent factors have sharpened these differences. The geographic and ecological conditions proper to Anatolia, added to the Turkmen and Kurdish cultural mix, and the specific adaptations of their enclosed forms of seminomadism and nomadism have meant a landscape favorable to the development of rich and varied pastoral practices.

Also, the 'entre-deux kurde' (dual Kurdish positions) as defined by (James (2011),), regarding the geographic (moutains and plains), economic (shepherds and farmers), and social (sedentary and nomadic) situations of this people since the Middle Ages, has deepened this variability. On this base, more recent factors have been added: the survival of a family agro-pastoral economy in spite of agrarian reforms (which had a little impact on the Kurdish countryside; Aksoy 1989) and globalization, the uneven and unequal distribution of modern methods and materials, a complex and conflicting geopolitical situation, and finally, the degree to which the tribes are isolated (the families encountered were always very surprised to discover, from my photos, the practices of Kurdish tribes from other regions).

In consequence, it is impossible to find uniform Kurdish pastoral practices, a phenomenon already observed by (Scalbert-Yücel (2006),) concerning Kurdish languages. However, in our view, the retribalisation described by (Van Bruinessen (2000)) was the most determining factor in maintaining and accentuating the variety of Kurdish pastoralism. The example of the Yörüks deserves to be mentioned here.

The Yörüks are pastoral Turkmen nomadic people, among the most ancient in Turkey. They claim to be of pure Turkish origin, being descendents and heirs of the ancient Seljuk conquerors of the Oghouz tribes, who came to Turkey in the eleventh century (Encyclopaedia Universalis,). We learn from (Bates (1973),), cited in (Salzman (1983),), that they 'could install themselves in the region they occupy now because the national government obliged the previous occupants, Turkmen judged too restless, to settle. Once in place, the Yörüks, having lost practically all their organization and their traditional political leaders, had to adapt to the interests and good will of the local farmers supported by the government.' However, among the Yörüks, the Sarikeçili community have attracted the attention of Turkish politicians and media over this last decade. Indeed, the Hurriyet Daily News (the oldest English language daily in Turkey) has, in the last 2 years, several times reported this tribe's difficulty in maintaining their traditional lifestyle (Cetin 2010,; Ocak 2010-2011,; Akatay 2011,; Van Herpen 2011,). The Sarikeçilis are said to be the 'last Turkmen nomadic tribes from Anatolia' and 'the only group representing the Turkish migration from Central Asia' (Ocak 2011,). They move every summer to the high planes of Mersin and to the Konya meadow in the winter (Ocak 2011,). In 2011, thanks to a new law passed by the Turkish Parliament, their traditions will now be protected by a special authorization to allow their goats to pasture on woodlands reserved for them. Indeed, the main problem of this tribe was 'how to feed their flock when crossing woodlands protected by the laws of the Water and Forest Office" (Ocak 2011,). We also learn that 'a demand will be made to the UNESCO for the Sarikecilis to be under immediate protection" (Ocak 2011).

How could those people 'having lost almost all their organization and traditional political leaders', have obtained such political and media attention for the sustainability 
of their traditions? The daily newspaper gives us a beginning of an answer in an article published in July 2011. Indeed, we discover that in order to preserve their culture, an association of the nomadic tribes and Turkmen was established in 2001. Later, in 2005, the group became a confederation (Toroslar Yörük Tûrkmen Federasyonu). Today, the federation has 420 branches throughout Turkey with more than 1 million members (Van Herpen 2011). It is chaired by Özbek Mustapha, the rich and powerful president of the Turkish Metal Union.

The example of the Sarikeçilis is therefore a striking model of community and votecatching responses by shepherds faced with a political agenda by the state (Salzman 1983). To the political weight gained by this community is here added the national identity issue (the only group that represents the original Turkish in-migration to the land which is now modern Turkey).

The retribalisation of the Kurdish tribes is a part of the same phenomenon, in a more regional manner, in the game of vote-catching at the local elections (Van Bruinessen 2000), and to a lesser extent, on one hand, because of the limits of Kurdish nationalism which at present has no state intermediary and on the other hand, because Kurdish elites are not aware of the cultural value of Kurdish pastoralism. We suggest that the tribal system has not only preserved the nomadic and seminomadic pastoral practices, but has also invigorated them. The kind of pastoralism thus maintained, which we have partially described in this paper, today constitutes a real pastoral heritage, including that of Anatolia, which still has to be assessed.

The case of the Sarikeçilis is a striking example of a communal response and of clientalist vote-catching. Should Kurdish pastoralism in Turkey, while also a heritage, be preserved? It is not up to us, of course, to judge the possible needs of the pastoral Kurdish tribes. However, certain aspects of this issue can be addressed.

Firstly, does it need to be preserved from this political environment described by Salzman? Clearly, we think that it does not. The Kurdish tribes have entered into the democratic Turkish game, and their nomadism has already been adapted to urbanization since the Middle Ages (James 2011) and seems to have become used to the ville-monde (Braudel 1979). Kurdish pastoral living space in Turkey does not now seem to be threatened.

Moreover, does Kurdish pastoralism need to be economically protected? It is certain that it does not correspond to the requirements of 'optimum economy' (smoothed version of productivism) of the European Union's Common Agricultural Policy, for example. However, whether it is the Sawar tribe, inserted into a dynamic, broader identity that is both territorial and cultural (a National Park and Alevis religious affiliation), the Alikan tribe with its mosaic tents and a remarkable ciziri breed of sheep, or even the Beritan tribe and its economic development, it is through the diversity of situations and responses that Kurdish transhumant pastoralism is able to prove its adaptability and malleability despite its complex and difficult geopolitical context. The Kerkulaxî clan, through adopting a corporate form which includes the former tribal allegiance, is accessing modernity, based on a recognized and assumed tradition, synthesized by a commercial logo. These responses enable us to catch a glimpse of a global economical evolution which could, perhaps, lead in the future to the labelling of all products originating from valued cultural and economic practices, meeting the standards of sustainable development (solar energy, among others, seems to answer a general demand on 
the mountain pastures). But for this to happen, the Turkish state should recognize the pastoral nomadic culture as a whole, without any ethnic or identity distinction or promotion; for example, it seems that in the case of the Sarikeçilis that their tribal dimension has already been accepted, and the pastoral nomadic culture should be able to act on its territory for its own preservation - a broad (and impossible) task.

Finally, does Kurdish pastoral life need to be preserved from anything else? Overgrazing (Atalay 2000,), waste management, access to schooling (Kurdish Human Rights Project 2007,), and the status of women (Gündüz-Hosgör and Smits 2006) are many other issues regarding the Kurdish tribes. Those subjects should be part of another study and are not developed here.

\section{Conclusion}

As is the case among their brethren in cities, the daily lives of these Kurdish shepherds are affected by the changes within their environment and the difficulties of the Turkish nation at whole, which in turn is shaken by the brutal confrontation encompassing the ideology of a nation-state, an obsession with Jacobin citizenship, secularism, centralized conformism, and the reality of this country with its ethnic and religious solidarities. The Kurdish shepherds' integration with the urban economy has increased and is symbolized through the use of external materials to make their tents and ease their daily chores, the abandoning of carpet weaving, and the usage of trucks for transhumance. This last change signifies as much a transformation of pastoral movement patterns as it does a controlling nation-state, where major roads become forced channels of movement. Notwithstanding, the pastoral and nomadic spirit is still strong.

Thus, in the area north of the old Fertile Crescent, many millennia after the domestication of sheep, we see a local and original form of sheep breeding being maintained, an integrated rural nomadism diversifying itself in a world with an urban majority. To be interested in Kurdish pastoralism today is to rediscover tribes ignored for almost 40 years, to become aware of the Anatolian pastoral heritage, to evaluate the diversity of the practices, and to pay attention to the answers for facing a complex and special situation. Finally, it means looking at the Kurdish people in a different way. This people of the margins (Thevenin 2008) is nevertheless more than just a people without a state.

\footnotetext{
Acknowledgements

This article would not have been possible without the essential and gracious support of Bernard Toutain of CIRAD, France. I am also very grateful to Carol, publisher of this journal, for her patience and readiness and to all the anonymous reviewers for their critical reviews. I especially wish to thank my translators, Rachael Brooke and Caroline Ferrari, for their patience, their willingness and generous approach. I am greatly indebted to them. Last but not least, I want to address a special thanks to all the Kurdish families who greeted me in their homes and allowed me to share a small part of their lives.
}

Authors' information

Michaël Thevenin is a French mountain leader who specializes in pastoralism. His work includes studies of the shepherds of southeastern France. Recently, he has worked with an independent nonacademic status for 6 years among the Kurdish shepherds of southeastern Turkey. Since 2008, he has hosted lectures and photo exhibitions on this subject in France, Belgium, and Germany. Currently, he is seeking funding in order to continue his studies more precisely.

Competing interests

The author declares that he has no competing interests. 


\section{References}

Akatay, J. 2011. Yörük at heart: keeping the nomad heritage alive. Hürriyet Daily News. http://www.hurriyetdailynews.com/n. php?n=yoruk-2011-02-22. Accessed July 2011.

Aksoy, S. 1989. Les systèmes de propriété foncière en Turquie. Cahiers Options Méditerranéennes 36: 42-45.

Andrew, PA. 1999. Felt tents and pavilions: the nomadic tradition and its interaction with princely tentage. (Koelner Ethnologishe Mitteilungen, Sonderband) London: Melisende.

Askin, Y, F Cengiz, A Elicin, M Ertugrul, and R Sonnez. 1989. Agricultures Méditerranéennes: la Turquie. Paris: Centre International de Hautes Études Agronomique Méditerranéennes.

Atalay, I. 2000. Les principaux facteurs de dégradation des pâturages en Turquie. http://medias.obs-mip.fr/www/Reseau/ Lettre/13bis/fr/12.TURQUIE.PDF. Accessed July 2011.

Bates, DG. 1973. Nomads and farmers: a study of the Yörük of southeastern Turkey. Michigan: University of Michigan Press.

Besikci, I. 1969. Dogu da Degisim ve Yapisal sorunlar (göçebe Alikan asireti). Structural changes and problems in Eastern (the nomadic tribe Alikan). AnkaraYurt Kitap Yayin.

Boulay, S. 2004. Quand un objet change de statut: trajectoire de la tente dans la société maure (Mauritanie). http://www. ethnographiques.org/2004/Boulay. Accessed April 2011.

Boulay, S. 2005. Genèse, représentations, et usages de l'espace de la famille chez les Bédouins maures (Mauritanie). Espaces et Sociétés 120-121: 141-161.

Bozarslan, H. 2002. sous la conduite de Dieckoff, A. and Kastoryano, R. Nationalisme en mutation en Méditerranée orientale. Paris: Centre National de la Recherche Scientifique Édition.

Braudel, F. 1979. Civilisation matérielle, économie et capitalisme, XVe-XVIlle siècle. Paris: Armand Colin.

Cetin, M. 2010. Genuine nomadic tribe wants to settle down. Hurriyet Daily News. http://www.hurriyetdailynews.com/n.php? n=genuine-nomadic-tribe-wants-to-settle-down-2010-08-26. Accesed July 2011.

De Tapia, S. 2007. L'agriculture turque face au défi de l'adhésion à l'Union Européenne. http://turcologie.u-strasbg.fr/dets/ images/travaux/agriculture\%20turque\%20et\%20adh\%E9sion\%20\%E0\%201\%5C\%27ue.pdf. Accessed July 2011.

Digard, JP, and MH Papoli-yazdi. 2008. Le pastoralisme mobile en Iran. Etudes Rurales 181: 89-102.

Encyclopaedia Universalis. Yörük. http://www.universalis.fr/encyclopedie/yoruk/. Accessed July 2011.

Epstein. H. The Awassi sheep with special reference to the improved dairy type. Rome: FAO Animal Production and Health Paper.

Fabre, P. 2002. Transhumance: relique du passé ou pratique d'avenir. France: Cheminement Edition.

Feilberg, CG. 1944. La tente noire. Contribution à l'histoire ethnographique culturel des nomades, Ecrits du Musée National, 11e ethnographique Copenhague, p.254.

Flamant, JC. 2006. La Turquie vues par le trou de la serrure. http://www.agrobiosciences.org/IMG/pdf/Flamant-Turquiecorrige.pdf. Accessed March 2011.

Fleming, GM. 1991. L' écologie et l'économie des villages Kurdes. Kurdish times 4: 157-181.

Frödin, J. 1944. Les formes de la vie pastorale en Turquie. Meddlelanden fran Upsala Universitets Geografiska Institution, sér. A(41) Särtryck ur Geografiska Annaler, Häft 4.

Gokalp, A. 1987. Le Dis de l'os et du clan. De l'ordre segmentaire oghouz au village Anatolien. L'Homme 27: 80-96.

Gündüz-Hosgör, A, and J Smits. 2006. The status of rural women in Turkey: what is the role of regional differences. Nijmegen Center for Economics, NiCE Working Paper 06-101, Radboud University Nijmegen.

Hütteroth, WD. 1959. Bergnomaden und Yaylabauern in mittel Kurdischen Taurus. Marburg: Marburg University Press. James, B. 2011. Une ethnographie succincte de "l'entre-deux kurde au Moyen-âge. Etudes Rurales 186: 21-42.

Johnson, DL. 1969. The nature of nomadism: a comparative study of pastoral migrations in Southwestern Asia and Northern Africa. Department of Geography Research Paper No. 118. Chicago: University of Chicago 32-37.

Kurdish Human Rights Project. 2007. Projet du Parlement Européen: l'augmentation du taux de suicide chez les femmes kurdes. Département Thématique C, Droit des Citoyens et Affaires Constitutionnelles. Bruxelles.

Mason, IL. 1967. The Sheep Breeds of the Mediterranean. Commonwealth Agricultural Bureaux, Farnham Royal, Bucks, England.

Ocak, S. 2010. Anatolian nomads face hard times. Hürriyet Daily News. http://www.hurriyetdailynews.com/n.php?n=anatoliannomads-having-hard-times-2010-05-17. Accessed July 2011.

Ocak, S. 2011. Nomads in Turkey to enjoy new state protections. Hürriyet Daily News. http://www.hurriyetdailynews.com/n. php?n = 8216turkish-maasais8217-to-have-special-law-2011-01-16. Accessed July 2011.

Öz, K. 2008. The last season: Shawaks. Documentary. Mezopotamia Cinema \& Yapim13 Film Production, Suncem Kocer, Turkey.

Papoli-yazdi, MH. 1991. Le nomadisme dans le nord du Khorasan. Paris-Téhéran: Institut Français de Recherche en Iran.

Richet, ME. 2011. Interview de Tezcan, A. http://www.lepetitjournal.com/eco-istanbul/economie-istanbul/73972-agricultureturquie-8-eme-producteur-mondial-mais-avec-quelle-productivite-html. Accessed April 2011.

Rollan, F. 2004. sous la direction de Bouix, M. Minorités et construction nationale. Pessac: Maison des Sciences de l'Homme d'Aquitaine.

Rowton, MB. 1974. Enclosed nomadism. Journal of Economic and Social History of the Orient 17: 1-30. doi:10.1163/ $156852074 \times 00011$

Salzman, PC. 1983. Les facteurs politiques déterminant l'avenir des peuples pasteurs. L'avenir des peuples pasteurs: compte rendu de la conférence tenue à Nairobi, Kenya, 4-8 August 1981. Ottawa: Centre de Recherches pour le Développement International.

Scalbert-Yücel, C. 2006. Les langues des kurdes de Turquie: la nécessité de repenser l'expression "langue kurde". Maison des Sciences de l'Homme, Langage et Société 17: 117-140.

Tekelioghu, Y. 1993. Agricultural policies and agrarian structures in Turkey. Cahiers Options Méditerranéennes 1, 4: 67-74.

Thevenin, M. 2008. Mardin, un balcon sur la Mésopotamie, et Diyadin, un village éphémère, et parce que c'est un peuple des marges. http://www.transhumance-kurde.com/. Accessed April 2011.

Van Bruinessen, M. 2000. Les Kurdes, etats et tribus. Etudes Kurdes 1: 9-31.

Van Bruinessen, M. 2001. Le débat sur l'identité ethnique des Alévis Kurdes. Etudes Kurdes 3: 7-41.

Van Herpen, W. 2011. Sarikeçiler struggling to hold on to their way of life. Hurriyet Daily News. http://www.hurriyetdailynews. com/n.php?n=sarikeciler-struggling-to-hold-on-the-way-of-life-2011-07-19. Accessed July 2011 
Walliser, Y. 2011. L'agriculture du Kurdistan irakien: entre destruction et reconstruction. Etudes Rurales 186: 133-148. Wikipedia. http://en.wikipedia.org/wiki/Ismail_Besikçi, http://tr.wikipedia.org/wiki/Mustafa_Özbek, http:/fr.wikipedia.org/wiki/ Alevisme. Accessed August 2011.

Yalçin, BC. 1986. Sheep and goats in Turkey. Rome: Food and Agriculture Organization of the United Nations.

doi:10.1186/2041-7136-1-23

Cite this article as: Thevenin: Kurdish Transhumance: Pastoral practices in South-east Turkey. Pastoralism:

Research, Policy and Practice 2011 1:23.

Submit your manuscript to a SpringerOpen ${ }^{\odot}$ journal and benefit from:

- Convenient online submission

- Rigorous peer review

- Immediate publication on acceptance

- Open access: articles freely available online

- High visibility within the field

- Retaining the copyright to your article

Submit your next manuscript at $\gg$ springeropen.com 